\title{
Geochemical Characteristics of Iron in Sediments from the Sea of Marmara
}

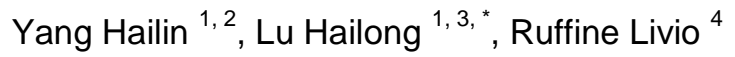 \\ ${ }^{1}$ Department of Energy and Resources Engineering, College of Engineering, Peking University, Beijing \\ 100871, P. R. China \\ ${ }^{2}$ School of Ocean Sciences, China University of Geoscience, Beijing 100083, P.R. China \\ ${ }^{3}$ Institute of Ocean Research, Peking University, Beijing 100871, P.R. China \\ ${ }^{4}$ IFREMER, Centre de Bretagne, Département REM, Unité des Géosciences Marines, Laboratoire des \\ Cycles Géochimiques et ressources (LCG), 29280 Plouzané, France
}

*Corresponding author : Hailong Lu, email address : $\underline{\text { hlu@pku.edu.cn }}$

\begin{abstract}
:
Two $\sim 1000 \mathrm{~cm}$ long sediment cores were recovered from the Sea of Marmara, one with the occurrence of gas hydrates in the Western High, and the other without hydrates in the Cinarcik Basin. Differences in mineralogical and chemical compositions have been identified between the two sediment cores. Based on the results of the mineralogical and geochemical analyses, the main sources of the sediments are quite similar for both investigated areas, but the authigenic components are different, particularly iron sulfides and carbonates. Authigenic Fe(II) carbonate are much higher in Core MRS-CS-05 in the Western High, while crystalline Fe(III) phases are more abundant in Core MRS-CS-16 in the Cinarcik Basin. Notably, the enrichments of greigite (Fe3S4), a metastable ferromagnetic iron sulfide mineral and intermediate polysulfide, as well as iron carbonates are identified at $400 \mathrm{cmbsf}$ with the maximum iron content in Core MRS-CS-05. These indicate the presence of a more reducing and acidic environment in the Western High, mainly due to higher organic matter content and seepage of heavy hydrocarbons in the sediments.
\end{abstract}

Keywords : Iron geochemistry, the Sea of Marmara, Sediment, Redox environment 


\section{Introduction}

On continental margins, cold seeps are places where hydrocarbon-rich fluids, especially methane, are transferred from the sedimentary sequence into the water column. The fluids migrating within the sedimentary column undergo partial physical and (bio-)chemical transformations, and the remaining fluid is discharged at the seafloor, allowing for the development of very diverse ecosystems (Zitter et al., 2008; Suess, 2014). Cold seep system may contain gas hydrates when an appropriate thermal regime is encountered in the sedimentary column (i.e., low temperature and high pressure) and the interstitial fluid is saturated with hydrate-forming gases like methane (Kvenvolden, 1988; Leifer and Patro, 2002; Tary et al., 2010). Natural-gas hydrate deposit represents an important site for hydrocarbon accumulation in the shallow sedimentary column, and the release of methane through gas seeps is often found associated with fractures.

In cold seeps, iron is a key reactive element in marine sediments and thus, it is highly subject to phase transformations by redox processes which change its valences according to the local conditions. Iron has different redox states $(-2$ to +7$)$, although $\mathrm{Fe}(\mathrm{II})$ and $\mathrm{Fe}(\mathrm{III})$ are 


\section{ACCEPTED MANUSCRIPT}

the most common in nature. it occurs as iron (oxyhydr)oxide $\left(\mathrm{Fe}^{\mathrm{III}}{ }_{5} \mathrm{HO}_{8} \cdot 4 \mathrm{H}_{2} \mathrm{O}, \gamma-\mathrm{Fe}{ }^{\mathrm{III}} \mathrm{OOH}\right.$, $\alpha-\mathrm{Fe}^{\mathrm{III}} \mathrm{OOH}, \mathrm{Fe}^{\mathrm{III}}{ }_{2} \mathrm{O}_{3}$, and $\left.\mathrm{Fe}^{\mathrm{II}} \mathrm{Fe}^{\mathrm{III}}{ }_{2} \mathrm{O}_{4}\right)$, carbonate $\left(\mathrm{Fe}^{\mathrm{II}} \mathrm{CO}_{3}\right)$, sulfide $\left(\mathrm{Fe}^{\mathrm{II}} \mathrm{S}_{2}, \mathrm{Fe}^{\mathrm{II}} \mathrm{S}\right.$, and $\left.\mathrm{Fe}^{\mathrm{II}} \mathrm{Fe}^{\mathrm{III}}{ }_{2} \mathrm{~S}_{4}\right)$, phosphate $\left[\mathrm{Fe}_{3}^{\mathrm{II}}\left(\mathrm{PO}_{4}\right)_{2} \cdot 8 \mathrm{H}_{2} \mathrm{O}\right]$, silicate minerals $\left(\mathrm{Fe}^{\mathrm{II}}\right.$ and/or $\mathrm{Fe}^{\mathrm{III}}$ in illite, smectite, and chlorite), etc. (Stumm and Sulzberger, 1992; März et al., 2008; Raiswell and Canfield, 2012; Rickard and Luther, 2013; Egger et al., 2015a). Usually, the transitions between each species depend on electron activity $(\mathrm{pE})$ and $\mathrm{pH}$, which are described in a diagram showing the various particulate and dissolved phases (Glasby and Schulz, 1999). Under anoxic conditions, the solubility of Fe(II) may greatly exceed the solubility of Fe(III) in seawater (Worsfold et al., 2014). The redox conditions in shallow marine sediments are generally related to the organic matter degradation in sediments (Berner, 1980; Wallmann et al., 2006). It is also closely associated with intensity and duration of the local flux of hydrocarbons (Claypool and Threlkeld, 1983; Boetius et al., 2000), especially at gas seeps (Malinverno and Pohlman, 2011). The redox conditions would change in response to the variations of hydrocarbon flux during the sedimentary history (Cappellen and Wang, 1996; Anbar and Knoll, 2002; Lyons and Severmann, 2006). The redox states of Fe, as well as other redox-sensitive elements, e.g., $\mathrm{Mn}$ and $\mathrm{Ce}$, might change during different stages of the sedimentary process, and thus they are considered as potential proxies of the redox conditions in sediments (Brookins, 1988; German and Elderfield, 1990; Thomson et al., 1996, 1998).

Several methods have been developed to study the speciation of iron in soils and sediments (Table 1). In marine sediments, the most common agent for extracting $\mathrm{Fe}(\mathrm{II})$-containing minerals including ferrous (oxyhydr)oxides and carbonate phases is $1 \mathrm{~mol}$ $\mathrm{L}^{-1} \mathrm{HCl}$ (Raiswell et al., 1994; Poulton et al., 2004). HCl-soluble iron represents a good 


\section{ACCEPTED MANUSCRIPT}

geochemical proxy for pyrite formation in organic carbon-enriched sediments (Raiswell et al., 2001). Considering the properties of gas- and hydrate-bearing sediments, samples are subjected to a sequential extraction procedure for iron using methods reported by using Poulton and Canfield (2005), and Egger et al. (2015b). By referring to the results of sequential extractions of elements in sediments, the geochemistry of the environmental-sensitive elements can be used as proxies to understand the environmental factors controlling the chemistry of seeping fluid (redox condition, $\mathrm{pH}$, etc.), gas composition, hydrate occurrence, and organic matter in sediments. Firstly, early diagenetic reactions (degradation of organic compounds and reduction of Fe-Mn oxyhydroxides) in marine sediments lead to a strong enrichment of trace elements (e.g., rare earth elements and metalloids) in pore waters (Bayon et al., 2004; Wang et al., 2014). Secondly, diagenetic Fe oxyhydroxides in sediments is always similar with Mn phases. Both Fe and $\mathrm{Mn}$ are present in the soluble in reduced form and the insoluble form as oxyhydroxides, and these redox states can interconvert in the vicinity of a redox boundary (Belzile et al., 1989; Lovley, 1991; Burdige, 1993; Davison, 1993). Finally, mineral precipitation at cold seeps may exhibit a wide range of mineralogical compositions. Consequently, studies of mineralogical compositions and chemical speciation of environment sensitive elements are important for elucidating the formation mechanism of mineralogy and trace elements in the sediments encountered at cold seeps.

Elemental geochemistry was investigated in two sediment cores collected from the Sea of Marmara during the MarsiteCruise Expedition, which was led by IFREMER (Institut Français de Recherche pour l'Exploitation de la Mer) in November 2014 on the $R / V$ Pourquoi 


\section{ACCEPTED MANUSCRIPT}

pas?. In this research, sediment analyses include measurements of TOC content, selected major and trace elements of the bulk solid, determination of the chemical speciation of Fe, Mn and Ce with sequential extraction methods, X-ray diffraction study of mineralogical compositions in sediments. A special emphasis is laid on the iron geochemistry. It is discussed primarily by combining its mineralogy, especially for the sulfide minerals, its speciation, and its relations with manganese, organic matter, and the flux of gases within the upper sedimentary layer.

\section{Geological setting}

The Sea of Marmara is an inland sea located within the Turkish territory that connects the Mediterranean Sea with the Black Sea. It is an active subsiding marine basin that is crossed from east to west by the North Anatolian Fault (NAF) (Armijo et al., 2005; Géli et al., 2008), one of the most seismically active faults on earth (Gasperini et al, 2001; Gasperini et al, to be submitted; Karabulut et al., 2001; Çağatay et al., 2012). The fault systems in the Sea of Marmara act as preferential conduits for the occurrence of multiple seeps, emitting fluids into seawater at the seafloor (Bourry et al., 2009; Ritt et al., 2010, Dupré, 2015; Ruffine et al., to be submitted).

Geologically, the Sea of Marmara contains three sub-basins known from east to west as the Tekirdag Basin, the Central Basin, and the Cinarcik Basin. These basins are separated from each other by two shallower topographic highs called the Western High and Central High (Fig. 1). According to CTD profiles in the Sea of Marmara, the temperature at the seafloor is approximately $15^{\circ} \mathrm{C}$ with a salinity of approximately $20-38 \%$ (Marsite Cruise 


\section{ACCEPTED MANUSCRIPT}

Report, 2014; Bourry et al. 2009). Based on previous studies of free gases and gas hydrates in the Sea of Marmara, the gases emitted at the Western and Central Highs were of thermogenic origin, whereas the gases emitted from the Cinarcik Basin were primarily microbial (Bourry et al., 2009; Ruffine et al., 2012; Ruffine et al, in press). The thermogenic gases come from the hydrocarbon reservoirs of the Thrace Basin and are partially stored as hydrates in the Western High, whereas the microbial gases of the Cinarcik Basin were derived from $\mathrm{CO}_{2}$ reduction at low temperatures (Gürgey et al., 2005; Bourry et al., 2009, Ruffine et al., to be submitted). Moreover, the gas hydrate deposit is closely associated with active seeps from which gas and oil are discharged (Ruffine et al., in press). To date, gas hydrates have not been discovered in the eastern part of the Sea of Marmara. This finding provides us an opportunity to compare the Fe geochemistry in the sediments with and without gas hydrates, and its relationships with gas seep activities. The samples studied here were collected from two sites during Leg 2 of Marsite expedition, Core MRS-CS-05 in the Western High, a site with strong gas seepage and hydrate occurrence, and Core MRS-CS-16 in Cinarcik Basin, a hydrate-free site.

\section{Materials and Methods}

\subsection{Site description and sample collection}

The main objectives of the MarsiteCruise expedition were (1) to deploy geodesic instrumentation for long-term monitoring of the NAF displacement, and (2) to investigate the geochemical dynamics of fluid discharged from seeps along the NAF and the secondary fault network. The map of the studied area and locations of the samples are shown in Fig. 1, and 


\section{ACCEPTED MANUSCRIPT}

the coordinates of the sediment cores are provided in Table 2. Sediment cores were recovered with a CALYPSO ${ }^{\circledR}$ piston corer on the Western High (MRS-CS-05) and in the Cinarcik Basin (MRS-CS-16). The sediments were generally clayey silt and greenish-gray in color. In contrast to the Core MRS-CS-16, a strong odor of $\mathrm{H}_{2} \mathrm{~S}$ and yellow tar spots characterized Core MRS-CS-05. The cores were cut to $1 \mathrm{~m}$ length and subsampled about 1 sample per meter for further analysis on board; the collected samples were stored at $-20^{\circ} \mathrm{C}$. Totally 21 samples, 10 from Core MRS-CS-05 and 11 from Core MRS-CS-16, were used for this study.

\subsection{Experimental and analytical methods}

\subsubsection{Sample preparation and mineralogical analysis}

Twenty-one sediment samples were freeze-dried and then were ground in an agate mortar to approximately $75-\mu \mathrm{m}$ particles in an $\mathrm{N}_{2}$ gas-filled glove box for further analyses. Sediment mineralogy was investigated by Powder X-ray diffraction (PANalytical X'Pert Pro) with $\mathrm{Cu} \mathrm{K} \alpha$ radiation $(40 \mathrm{kV} \times 40 \mathrm{~mA})$ at the Analytical Instrumentation Center of Peking University in Beijing. The total carbon (TC) and total sulfur (TS) contents were determined after dry combustion using the Analytikjena $\mathrm{C} / \mathrm{S}$ elemental analyzer at the Analytical Instrumentation Center of Peking University. The total organic carbon (TOC) content was measured with the oxidative pyrolysis potential method after the inorganic carbon was

removed with $1 \mathrm{~mol} \mathrm{~L}^{-1} \mathrm{HCl}$. The total inorganic carbon (TIC) content was calculated as the difference between the total carbon (TC) and total organic carbon (TOC) contents.

\subsubsection{Compositional analysis of bulk sediments}

For the elemental analysis of bulk sediment, samples, standard reference sediments and 
one blank were digested with a concentrated acid mixture $\left(\mathrm{HNO}_{3}, \mathrm{HCl}, \mathrm{HF}\right.$, and $\left.\mathrm{HClO}_{4}\right)$ according to United States Environmental Protection Agency Method 3050B, and the whole process was controlled by a microwave-assisted program (USEPA, 1996).

The Al, Mg, Ca, Na, K, Fe, Cr, P, Ti, and V contents were determined using inductively coupled plasma optical emission spectrometry (ICP-OES, IRIS Intrepid II, ThermoScientific), and the $\mathrm{Cd}, \mathrm{Ce}, \mathrm{Co}, \mathrm{Cu}, \mathrm{Mn}, \mathrm{Ni}, \mathrm{Pb}, \mathrm{Sb}, \mathrm{Sc}$, and $\mathrm{Zn}$ contents were measured using inductively coupled plasma mass spectrometry (ICP-MS, X Series II, ThermoScientific) at the Analytical Instrumentation Center of Peking University. The accuracies of the measurements were examined using standard reference sediment materials (GSD6, GSD7a, and GBW07335). Because the contents of elements in sediments are in different ranges, different units have been applied (for the major element, weight percentage are presented in \%). The concentrations of these elements were within the certified ranges, with a precision greater than 5\%. SPSS statistical software was used for the correlation analysis between elements.

\subsubsection{Sequential extraction of elements in sediments}

The sequential extraction protocol for Fe and Mn described by Kasten et al. (1998), Poulton and Canfield (2005), and Egger et al. (2015b) was adopted for this research, and a brief summary of the Fe and Mn species that were extracted at each step is shown in Table 3. The Fe and Mn contents in each extraction solution were determined using inductively coupled plasma mass spectrometry (ICP-MS, X Series II, ThermoFischer, Germany) at the Analytical Instrumentation Center of Peking University.

The sequential extraction procedure aims to dissolve the solid phases targeted by each 


\section{ACCEPTED MANUSCRIPT}

extractant and allows mineral phase separation from the sediment (Table 1 and Table 3). Iron, a redox-sensitive element, occurs in different mineral phases. Therefore, a well-designed sequential extraction protocol is critical for determining the redox states of Fe and their host phases in the sediments from the Sea of Marmara.

For the sequential extraction method, the data quality and method reliability were assessed by the yield, the sum of individual extraction fractions for each element divided by its content in the bulk sediment. Generally, the results are acceptable when the yield is between 80 and 120\% (Poulton and Canfield, 2005; Larner et al., 2006; Claff et al., 2010). The yield for Fe, Mn, and Ce in the studied sediments range from 91 to 108\%, 80 to $120 \%$, and $82-160 \%$, respectively. A yield of $160 \%$ for Ce is not acceptable, probably caused by either the dilution of solution or the heterogeneity of the sediments. The unacceptable high yield of $\mathrm{Ce}$ is found with a layer where the content of $\mathrm{Ce}$ is the lowest. So the yield of $\mathrm{Ce}$ for this layer might be compromised by dilution when the same dilution for sample with relatively high content of Ce was applied. Although the test specimens for both total digestion and sequential extraction were collected from the same layer, they might be suffered from the heterogeneity of Ce distribution in the sediments.

\subsubsection{Sequential analysis of iron sulfides}

Iron sulfides are reported to be the most significant sink of reduced sulfur and iron-related minerals in marine environment. The operationally defined sedimentary components of acid volatile sulfide (AVS, i.e., amorphous FeS, mackinawite, and greigite) and chromium reducible sulfur (CRS, mostly pyrite) were determined using the two-steps 


\section{ACCEPTED MANUSCRIPT}

sequential extraction method. $200 \mathrm{mg}$ sample powder was reacted with HCl-based extractant and the experimental setup was a closed system as shown by Gröger et al (2010). It is noteworthy that all the reaction processes were under the $\mathrm{N}_{2}$ atmosphere to avoid the possible oxidation of iron and sulfur. Besides, a pure pyrite standard reference sample was employed to verify the quality of the analysis of the sediments, and the yield of the parallel replicate pure pyrite standard was $93.5 \%$.

\section{Results}

\subsection{Mineralogical composition}

As shown in Fig. 2 and Fig. $1 \mathrm{~S}$ of the supplementary materials, the mineralogical compositions of bulk sediments contain quartz, carbonates, clay minerals, mica minerals, $\mathrm{Fe}$ sulfides and Fe (hydr)oxides. Carbonate minerals include calcite, aragonite, vaterite, and possibly trace amounts of dolomite and siderite. The dominant clay minerals include chlorite, illite, and kaolinite.

Iron sulfides include pyrite and metastable Fe sulfides of mackinawite and greigite, and Fe hydroxides mainly are hematite, akageneite, lepidocrocite, and goethite. Notably, greigite $\left(\mathrm{Fe}_{3} \mathrm{~S}_{4}\right)$ was identified at the layer of $400 \mathrm{cmbsf}$ for the Core MRS-CS-05 in the Western High (Fig. 3).

\subsection{Geochemistry of bulk sediments}

The vertical distributions of $\mathrm{Fe}, \mathrm{Mn}, \mathrm{Ce}$, and other associated elements in the two sediment cores are shown in Fig. 4. The values for $\mathrm{Cd}, \mathrm{Co}, \mathrm{Cr}, \mathrm{Cu}, \mathrm{Ni}, \mathrm{Pb}, \mathrm{Sb}, \mathrm{Sc}, \mathrm{Ti}, \mathrm{V}, \mathrm{Zn}$, 


\section{ACCEPTED MANUSCRIPT}

$\mathrm{Al}, \mathrm{Mg}, \mathrm{Ca}, \mathrm{Na}$, and $\mathrm{K}$ were fairly constant, therefore they are not displayed here but are presented in the supplementary data (Fig. $2 \mathrm{~S}$ and Table $1 \mathrm{~S}$ ).

The $\mathrm{Al} / \mathrm{Ti}$ ratio is used as an index of detrital aluminosilicates (Toyoda and Masuda, 1990; Bayon et al., 2004), because Al- and Ti-containing minerals are generally stable in diagenetic processes. As shown in Fig. 5a, the Al/Ti ratios for all the sediments obtained from the two sites were approximately 18. As discussed previously, $\mathrm{Fe}$ and $\mathrm{Mn}$ might have undergone state changes due to the changing redox conditions of their surrounding environments during the sedimentary history, and this change is reflected in the $\mathrm{Fe} / \mathrm{Al}$ and $\mathrm{Mn} / \mathrm{Al}$ ratios. The trends in the $\mathrm{Fe} / \mathrm{Al}$ and $\mathrm{Mn} / \mathrm{Al}$ ratios along the two sediment profiles are shown in Fig. 5b and Fig. 5c. The Fe/Al ratios for the sediments from the two sites are generally similar; however, significant Fe enrichments are identified at the interval of 400-600 cmbsf for Core MRS-CS-05. The Mn/Al ratios of the sediments are nearly constant along the full length of the Core MRS-CS-05, with the exception of $400 \mathrm{cmbsf}$, where a positive anomaly is observed. For the Core MRS-CS-16, the Mn/Al ratios in the sediments are generally higher than those at site MRS-CS-05 and are more variable with depth.

Fig. 4 shows the distributions of TIC along the two sediment profiles. TIC values are much lower for Core MRS-CS-05 than for Core MRS-CS-16 within the first $600 \mathrm{cmbsf}$. Both cores exhibit similar values at approximately $800 \mathrm{cmbsf}$. At greater depths, the values increase up to $9 \%$ for the Core MRS-CS-05.

As shown in Fig. 4, the TOC contents remain fairly constant along Core MRS-CS-16, with an average of $1.2 \%$, but higher values are measured for Core MRS-CS-05. In Core MRS-CS-05, detailed observations indicate that TOC contents increase slightly with depth in 


\section{ACCEPTED MANUSCRIPT}

the upper $200 \mathrm{cmbsf}(1.8 \%)$, decrease to the lowest values at $400 \mathrm{cmbsf}(1.2 \%)$, and then exhibit enrichment from 400 to $1000 \mathrm{cmbsf}$, with two peaks at $600 \mathrm{cmbsf}(2.2 \%)$ and 1000 cmbsf $(2.1 \%)$.

The total sulfur (TS) contents in both cores are depicted in Fig. 4. The TS contents in the Core MRS-CS-05 are generally higher than the contents in the Core MRS-CS-16, particularly for samples collected from the upper part of the sedimentary column. The TS values for Core MRS-CS-05 range from 1.0 to $1.5 \%$, with an exceptional peak of $2.1 \%$ at $600 \mathrm{cmbsf}$. The TS contents in the Core MRS-CS-16 are generally less than $1.0 \%$ and are even less than $0.2 \%$ in the topmost $200 \mathrm{cmbsf}$.

Cerium is sensitive to the environmental redox conditions (Liu et al., 1988; German and Elderfield, 1990). The distribution of Ce along the two sediment cores is shown in Fig. 4. The Ce contents in the sediments of Core MRS-CS-05 and Core MRS-CS-16 are generally approximately $60 \mathrm{mg} \mathrm{kg}^{-1}$. However, an exceptionally low value of $33 \mathrm{mg} \mathrm{kg}^{-1}$ is found at $600 \mathrm{cmbsf}$ in the Core MRS-CS-05.

To summarize the results presented above, significant changes in the $\mathrm{Fe}, \mathrm{Mn}, \mathrm{Ce}, \mathrm{TIC}$, TOC, and TS contents are observed in Core MRS-CS-05 within the sedimentary intervals of $400-600$ cmbsf.

\subsection{Chemical speciation of $\mathrm{Fe}, \mathrm{Mn}$, and $\mathrm{Ce}$ in sediments}

The Fe and Mn contents determined by sequential extraction in the two sediment profiles are shown in Fig. 6a-d, and the Ce contents are shown in Fig. 3S. The differences in the yield for $\mathrm{Fe}, \mathrm{Mn}$ and $\mathrm{Ce}$ are related to their overall contents in sediments: Fe represents > 


\section{ACCEPTED MANUSCRIPT}

$4 \%$ of the sediment content and is considered as a major element. Mn ranges from 0.03 to $0.4 \%$ and is a minor element, while $\mathrm{Ce}$ is $<0.0063 \%$ and is a trace element. As a result, the discussion of the geochemical environments at the Western High and the Cinarcik Basin are mainly based on the results of Fe speciation observed in sediments, underpinned by the data on the speciation of $\mathrm{Mn}$.

For Core MRS-CS-05, the concentrations of Fe are $665-4078 \mathrm{mg} \mathrm{kg}^{-1}$ (corresponding to $1.6-7.4 \%$ of the bulk sediment) in the carbonate-associated fraction (siderite and ankerite), 891-6124 $\mathrm{mg} \mathrm{kg}^{-1}(2.2-11 \%)$ in the easily reducible fraction (amorphous oxides: ferrihydrite and lepidocrocite), $775-1486 \mathrm{mg} \mathrm{kg}^{-1}(1.7-3.5 \%)$ in the reducible fraction (crystalline oxides: goethite, hematite, and akageneite), $1275-1872 \mathrm{mg} \mathrm{kg}^{-1}(2.3-4.2 \%)$ in the recalcitrant oxide (magnetite), and 33576-45454 $\mathrm{mg} \mathrm{kg}^{-1}(69-97 \%)$ in the residual fraction (mainly silicates).

For Core MRS-CS-05, the concentrations of Mn vary between 64 and $390 \mathrm{mg} \mathrm{kg}^{-1}$ (corresponding to $12-42 \%$ of the bulk sediment) in the carbonate-associated fraction $\left(\mathrm{MnCO}_{3}\right.$ and $\mathrm{Mn}-\mathrm{Ca}$ carbonates), from 15 to $403 \mathrm{mg} \mathrm{kg}^{-1}(2.7-26 \%)$ in the easily reducible fraction (amorphous oxides: birnessite, vernadite, nsutite, and pyrolusite), $1.5-7.7 \mathrm{mg} \mathrm{kg}{ }^{-1}$ $(0.24-1.3 \%)$ in the reducible fraction (crystalline oxides: manganite and bixbyite), $8.0-41 \mathrm{mg}$ $\mathrm{kg}^{-1}(1.0-6.0 \%)$ in the recalcitrant oxide (hausmannite), and $236-635 \mathrm{mg} \mathrm{kg}^{-1}(27-80 \%)$ in the residual fraction.

For Core MRS-CS-16, the concentrations of Fe change from 423 to $1834 \mathrm{mg} \mathrm{kg}^{-1}$ (corresponding to $1.0-4.0 \%$ of the total $\mathrm{Fe}$ in bulk sediment) in the carbonate-associated fraction, $1545-2515 \mathrm{mg} \mathrm{kg}^{-1}(3.5-5.8 \%)$ in the easily reducible fraction (amorphous oxides), 2107-9980 $\mathrm{mg} \mathrm{kg}^{-1}$ (4.9-21\%) in the reducible fraction (crystalline oxides), 1153-3556 mg 


\section{ACCEPTED MANUSCRIPT}

$\mathrm{kg}^{-1}(2.5-7.8 \%)$ in the recalcitrant oxide fraction, and $28913-39750 \mathrm{mg} \mathrm{kg}^{-1}(62-89 \%)$ in the residual fraction.

For Core MRS-CS-16, the concentrations of Mn range from 646 to $3379 \mathrm{mg} \mathrm{kg}^{-1}$ (corresponding to $48-87 \%$ of the total $\mathrm{Mn}$ in bulk sediment) in the carbonate-associated fraction, 35-105 $\mathrm{mg} \mathrm{kg}^{-1}(2.1-5.2 \%)$ in the easily reducible fraction, 5.6-69 $\mathrm{mg} \mathrm{kg}^{-1}$ $(0.4-3.0 \%)$ in the reducible fractions (crystalline oxides), $10-55 \mathrm{mg} \mathrm{kg}^{-1}(0.5-4.2 \%)$ in the recalcitrant oxide, and $207-427 \mathrm{mg} \mathrm{kg}^{-1}(7.6-46 \%)$ in the residual Mn fraction.

\subsection{Distribution of iron sulfides}

In addition to the above species of iron, the contents of iron sulfides (AVS and CRS) in Core MRS-CS-05 and Core MRS-CS-16 are presented in Fig. 7. Values of AVS (amorphous FeS, mackinawite, greigite, etc.) are generally lower than CRS (mainly pyrite) in the sediments. The results obtained reveal that amorphous FeS, mackinawite, and greigite contents remain relatively consistent $(-0.05 \%$ on average) with increasing depth in these cores, while it seems AVS are somewhat higher in the top of Core MRS-CS-05 than the top of Core MRS-CS-16. The contents of pyrite vary from $0.1-0.98 \%$ in the two cores, with two sharp increases at depth $400 \mathrm{cmbsf}$ and $600 \mathrm{cmbsf}$ in the Core MRS-CS-05, and most of the samples of Core MRS-CS-05 are with higher pyrite contents than those of Core MRS-CS-16.

\section{Discussion}

\subsection{Effect of seeping hydrocarbons on geochemical environment in sediments}

From the Al/Ti ratio, the sources for detrital materials of sediments are similar in the Western High and the Cinarcik Basin. However, significant differences can be identified in 


\section{ACCEPTED MANUSCRIPT}

the contents of $\mathrm{Fe}, \mathrm{Mn}$, TIC and TOC, the chemical speciation of iron and authigenic minerals in sediments between the two sites. These differences can be summarized as that, compared with the Cinarcik Basin (1) the contents of Fe, Mn and TIC are generally lower, with exceptions of Fe enrichment around $400 \mathrm{cmbsf}$ and $600 \mathrm{cmbsf}$, (2) TOC and TS are much higher, (3) iron in the carbonate-bound fraction are higher, and (4) a metastable iron sulfide mineral, greigite, is identified at $400 \mathrm{cmbsf}$ in the Western High. Obviously, all these differences are associated with the diagenetic processes in sediments: Fe, Mn, TOC, and TS could be involved in the redox reactions; carbonate bound iron (in the form of siderite) are from authigenic carbonate formation; and greigite is an authigenic sulfide mineral which could have been formed in special geochemical environment.

As the sediment cores are only of about $10 \mathrm{~m}$ long, they should have primarily experienced early diagenesis. In marine sediments, early diagenetic reactions are mainly a sequence of microbial metabolic activity, involving redox reactions of reducing oxygen, nitrate, manganese and iron oxides, sulfate and carbon dioxide (Burdige, 1993; Roberts and Weaver, 2005). Organoclastic sulfate reduction (Eq. 1) is the most important redox reaction occurring in shallow marine sediments (Claypool and Kaplan, 1974, Berner, 1980; Lovley, 1991). However, anaerobic oxidation of methane (Eq. 2) is also significant and can play an even more important role in sulfate depletion when there is a large flux of hydrocarbons (mainly methane) (Reeburgh, 1976; Borowski et al., 1996; Ruffine et al., 2015; De Prunelé et al, 2017).

$$
\begin{gathered}
\mathrm{CH}_{2} \mathrm{O}+\mathrm{SO}_{4}{ }^{2-} \rightarrow \mathrm{H}_{2} \mathrm{~S}+2 \mathrm{HCO}_{3}{ }^{-} \\
\mathrm{CH}_{4}+\mathrm{SO}_{4}{ }^{2-} \rightarrow \mathrm{HCO}_{3}{ }^{-}+\mathrm{HS}^{-}+\mathrm{H}_{2} \mathrm{O}
\end{gathered}
$$




\section{ACCEPTED MANUSCRIPT}

Intensive hydrocarbon seepages were observed at both studied sites, although the compositions of the seeping gases were quite different between the two sites (Ruffine et al., in press). In the Western High, the methane was the major components of the gases, and account for less than $90 \%$, the remaining components being heavy hydrocarbons with ethane $(1.0-3.5 \%)$, propane $(2.5-4.0 \%)$, butane $(\sim 1.0 \%)$, and pentane $(\sim 0.2 \%)$, and $\mathrm{CO}_{2}(\sim 4-9 \%)$. It should be noticed the occurrence of seepage of petroleum oil in the Western High, and part of the $\mathrm{CO}_{2}$ was diagnosed as being the product of petroleum degradation. In the Cinarcik Basin, the gases were predominantly methane $(>99.6 \%)$ with trace amount of $\mathrm{CO}_{2}(<0.18 \%)$ and $\mathrm{N}_{2}$ $(<0.26 \%)$ while heavy hydrocarbons were generally $<0.001 \%$. Pore-water data from push cores displayed a deeper sulfate depletion zone in Cinarcik Basin close the Core MRS-CS-16 (Ruffine et al., in press). Crémière et al. (2017) found that the sediments would be more reducing and acidic when TOC content is higher or when the hydrocarbon seepage is more intensive. By comparing with the Cinarcik Basin, because the TOC of the Western High were higher and the gases contained a relatively high content of heavy hydrocarbons, there are more electron receptors, leading to a sedimentary environment more reducing and acidic. As a result, the sulfate reduction zone would be much shallower, more iron oxides would be reduced, and more $\mathrm{Fe}^{2+}$ would migrate upward and then react with $\mathrm{HS}^{-}$and $\mathrm{S}^{2-}$ to form iron sulfides. This may explain the higher TS, CRS and AVS in Core MRS-CS-05 compared to Core MRS-CS-16. In comparison with MRS-CS-16 in the Cinarcik Basin, MRS-CS-05 in the Western High sediments contain higher content of organic carbon, and seeping fluids have higher $\mathrm{CO}_{2}$ content along with significant content of heavy hydrocarbons. The $\mathrm{CO}_{2}$ from the oxidation of organic matter and in the seeping fluid will make the sedimentary environment 


\section{ACCEPTED MANUSCRIPT}

in MRS-CS-05 more acidic than around MRS-CS-16. Thus, more biogenic carbonate might have been dissolved (Liu et al., 2017). This could help to explain why TIC in bulk sediments and reducible fraction of iron in Western High are lower than those in the Cinarcik Basin, although more evidence will be needed.

\subsection{Implications of the chemical speciation of $\mathrm{Fe}, \mathrm{Mn}$, and $\mathrm{Ce}$ in sediments}

The total Fe contents display two distinct maxima (5.5\% at $400 \mathrm{cmbsf}$ and $5.3 \%$ at 600 cmbsf) in Core MRS-CS-05. The first occurs at $400 \mathrm{cmbsf}$ and mainly consists of carbonate Fe(II) phases of easily reducible amorphous oxides, such as ferrihydrite and lepidocrocite. In contrast, the lowest values of total Fe content occurs at the same depth (4.0\% at $400 \mathrm{cmbsf})$ in the Core MRS-CS-16 and mainly consists of crystalline Fe(III) phases, such as goethite and hematite (Fig. 6a and Fig. 6b). The second maximum observed in the Core MRS-CS-05 occurs at $600 \mathrm{cmbsf}$ and matches the highest value of the total S content (2.1\%). According to the results presented in Table 4, the pronounced enrichment of Fe sulfides is substantiated by the strong correlation between the iron contents and the solid phase sulfur concentration profile $(r=0.785, p<0.01)$. This observation might imply that, iron oxides are reduced under strongly reducing and acidic condition, and the produced divalent iron will form iron sulfides and carbonates at suitable location while migrating through sediments in the Western High.

In marine sediments, Fe generally forms pyrite by complexing with sulfide in the sulfate reduction zone. However, when either $\mathrm{Fe}^{2+}$ is in excess or sulfide is not sufficient to sustain pyrite formation, monosulfides such as mackinawite (tetragonal FeS), amorphous $\mathrm{FeS}$, and greigite are formed (Rowan et al., 2005; Morgan et al., 2012). The formation of greigite 


\section{ACCEPTED MANUSCRIPT}

requires the following conditions (Roberts and Weaver, 2005; Hunger et al., 2007): (1) $\mathrm{Fe}^{2+}$ is in excess so that the reaction of $\mathrm{Fe}^{2+}$ with $\mathrm{S}^{2-}$ cannot be completed, (2) strongly reducing and comparatively acidic $(\mathrm{pH}<5)$ environment. Greigite was identified in Core MRS-CS-05 on the Western High but not in Core MRS-CS-16 from the Cinarcik Basin, indicating that the sedimentary environment of MRS-CS-05 was more reducing and acidic. The enrichment of greigite at $\sim 400 \mathrm{cmbsf}$ might imply a significant change in the redox conditions in sediments that the environment was more reducing and acidic, suitable for the formation of greigite (Rowan, 2005; Roberts and Broadbent, 2005; Roberts, 2015).

The seepage occurrence and intensity of several gas streams in the Western High and the Cinarcik Basin were episodic (Tryon et al., 2012; MarsiteCruise Report, 2014; Ruffine et al., in press), leading to fluctuations in the local redox conditions. It has been shown that anaerobic oxidation of methane $(\mathrm{AOM})$ is the main process responsible for sulfate depletion within the sedimentary column at gas seep area in the Sea of Marmara (Halback, 2014; Ruffine et al., 2015). Thus, when there was no seeping almost no hydrocarbons would flow upward for the reduction of $\mathrm{SO}_{4}{ }^{2-}$, and consequently the local environment would become more oxidizing. However, this change in the redox conditions could be mediated by the occurrence of gas hydrates. Indeed, the stable occurrence of gas hydrates requires that its surrounding pore water has to be saturated with hydrate-forming gases. When it is not the case, gas hydrate would be dissociated to release gases into pore water to preserve the thermodynamic equilibrium. As a result, the presence of gas hydrates in the sediment would maintain reducing conditions in core MRS-CS-05.

The total Mn content in Core MRS-CS-16 is approximately 1-7.5 times higher than the 


\section{ACCEPTED MANUSCRIPT}

values obtained in the Core MRS-CS-05. Because the reduced form of $\mathrm{Mn}$ (II) is soluble (Nealson and Saffarini, 1994), the chemical speciation and the contents of Mn should be related to the local redox condition in sediments. As discussed above, Core MRS-CS-05 from the Western High is more reducing and acidic as it is affected by higher TOC in sediments and high flux of heavy hydrocarbons in seeping fluid, so the lower manganese contents might be caused by the migration of more manganese out of the sediments in this environment.

As indicated by the results of the selective extractions for manganese, the contents of the $\mathrm{Mn}(\mathrm{II})$ carbonate are much lower in Core MRS-CS-05 than in Core MRS-CS-16, while the contents of amorphous Mn (IV) are much higher. Equation 3 shows the reaction between methane and manganese oxide. Based on this equation more manganese would be reduced in MRS-CS-05 in the Western High, because the organic carbon content in the sediment is higher and the presence of heavy hydrocarbons and petroleum oil in seeping fluid can also get manganese oxide reduced. As a result, the sedimentary environment in sediments of Core MRS-CS-05 might be more suitable for the migration of manganese out of the sediment and that in sediments of Core MRS-CS-16 for a better formation of Mn(II) carbonate.

$$
\mathrm{CH}_{4}+4 \mathrm{MnO}_{2}+7 \mathrm{H}^{+} \rightarrow \mathrm{HCO}_{3}^{-}+4 \mathrm{Mn}^{2+}+5 \mathrm{H}_{2} \mathrm{O} \quad \text { (Eq. 3) }
$$

Ce is generally an effective proxy of redox variations (German and Elderfield, 1990). The contents of Ce are less than $60 \mathrm{mg} \mathrm{kg}^{-1}$ in the sediments from both the Western High and the Cinarcik Basin, so it is hard to form as minerals itself and its geochemical behaviors may be efficiently concentrated through the redox cycling of Fe and Mn (Braun et al., 1990; Pattan et al., 2005). As discussed in the Section of Methodology, the analytical results of Ce in this research are with comparatively large uncertainty due to several reasons, the Ce data 


\section{ACCEPTED MANUSCRIPT}

of the samples cannot provide a reliable proxy of the redox conditions of the local geochemical environment in sediments. Consequently, the chemical speciation of Fe could act as a proxy for gas seepage site in the sedimentary environment.

\section{Conclusions}

In this study, the geochemical characteristics of Fe in the sediments from the Sea of Marmara were investigated. The main findings can be summarized as follows.

(1) Although the source of the detrital materials for the sediments are similar in the Western High and the Cinarcik Basin, significant differences have been identified in the authigenic minerals, such as carbonates, iron sulfides, and some Fe (hydr)oxides.

(2) The speciation of $\mathrm{Fe}$ in the sediments from the two sites is different: Sediment from the Core MRS-CS-05 is characterized by a large fraction of Fe(II) phases such as siderite and ankerite, whereas Fe(III) phases are the dominant species in Core MRS-CS-16 in the Cinarcik Basin. Besides, greigite $\left(\mathrm{Fe}_{3} \mathrm{~S}_{4}\right)$ was identified at the depth of the maximum iron content in the Core MRS-CS-05, and this is indicative of strongly reducing and acidic environment.

(3) The differences in Fe minerals and Fe speciation in the two studied sites resultfrom the differences in TOC of sediments and the compositions of the gases in the seeps: higher TOC and presence of heavy hydrocarbons associated with the strong seepage activities generate more reducing and acidic conditions on the Western High and lead to the formation of more authigenic minerals. 


\section{ACCEPTED MANUSCRIPT}

\section{Acknowledgments}

This study was supported by grants from China Geological Survey (GZH201500306, HD-JJHT-20) to H.L., the China Postdoctoral Science Foundation (2016M590015) and the Fundamental Research Funds for the Central Universities (53200759060) to H.Y. The scientific expedition was partially funded by the EU to monitor earthquakes and mitigate natural hazards. We thank the captain and crew of the RV Pourquoi pas?, as well as the crew of the ROV Victor-6000 for their technical support and advice. Financial support for the cruise was provided by the European program «MARsite», under the call ENV.2012.6.4-2: "Long-term monitoring experiment in geologically active regions of Europe prone to natural hazards: the Supersite concept". Partial financial support was also provided by the "Laboratoire d'Excellence" LabexMER (ANR-10-LABX-19) through the MicroGaMa and MISS Marmara projects, which were co-funded by a grant from the French government under the program "Investissements d'Avenir". We appreciate the anonymous reviewers for their constructive comments and suggestions, which are of great help in improving the quality of the paper. We would also like to thank Qian Zhang of University of Maryland Center for Environmental Science, who has always been very supportive in revising the manuscript.

\section{References}

Anbar, A.D., Knoll, A.H., 2002. Proterozoic ocean chemistry and evolution: a bioinorganic bridge? Science 297(5584), 1137-1142.

Armijo, R., Pondard, N., Meyer, B., Uçarkus, G., Mercier de Lépinay, B., Uçarkus. G., the Marmarascarps Cruise Party, 2005. Submarine fault scarps in the Sea of Marmara pull - 


\section{ACCEPTED MANUSCRIPT}

apart (North Anatolian Fault): implications for seismic hazard in Istanbul. Geochem. Geophy. Geosy. 6(6), 453-468.

Bayon, G., German, C.R., Burton, K.W., Nesbitt, R.W., Rogers, N. (2004). Sedimentary $\mathrm{Fe}-\mathrm{Mn}$ oxyhydroxides as paleoceanographic archives and the role of aeolian flux in regulating oceanic dissolved REE. Earth Planet. Sc. Lett. 224(3-4), 477-492.

Belzile, N., De Vitre, R.R., Tessier, A., 1989. In situ collection of diagenetic iron and manganese oxyhydroxides from natural sediments. Nature 340(6232), 376-377.

Berner, R.A., 1980. Early diagenesis: A Theoretical Approach, Princeton University Press, Princeton, N.J., 241p.

Boetius, A., Ravenschlag, K., Schubert, C.J., Rickert, D., Widdel, F., Gieseke, A., Amann, R., Jørgensen, B.B., Witte, U., Pfannkuche, O., 2000. A marine microbial consortium apparently mediating anaerobic oxidation of methane. Nature 407(6804), 623-626.

Borowski, W.S., Paull, C.K., Ussler, W.I., 1996. Marine pore-water sulfate profiles indicate in situ methane flux from underlying gas hydrate. Geology 24(7), 655-658.

Bourry, C., Chazallon, B., Charlou, J.L., Donval, J.P., Ruffine, L., Henry, P., Geli, L., Çagatay, M.N., İnan S., Moreau, M., 2009. Free gas and gas hydrates from the Sea of Marmara, Turkey: chemical and structural characterization. Chem. Geol. 264(1-4), 197-206.

Braun, J.J., Pagel, M., Muller, J.P., Bilong, P., Michard, A., Guillet, B., 1990. Cerium anomalies in lateritic profiles. Geochim. Cosmochim. Ac. 54(3), 781-795.

Brookins, D.G., 1988. Eh-pH Diagrams for Geochemistry. Springer-Verlag. 


\section{ACCEPTED MANUSCRIPT}

Burdige, D.J., 1993. The biogeochemistry of manganese and iron reduction in marine sediments. Earth-Sci. Revi. 35(3), 249-284.

Cappellen, P.V., Wang, Y.F., 1996. Cycling of iron and manganese in surface sediments: a general theory for the coupled transport and reaction of carbon, oxygen, nitrogen, sulfur, iron, and manganese. Am. J. Sci. 296(3), 197-243.

Çağatay, M.N., Erel, L., Bellucci, L.G., Polonia, A., Gasperini, L., Eriş, K.K., Sancar, Ü., Biltekin, D., Uçarkuş G., Ülgen, U.B., Damcı E., 2012. Sedimentary earthquake records in the İzmit Gulf, Sea of Marmara, Turkey. Sediment. Geol. 282(1), 347-359.

Chester, R., Hughes, M.J., 1967. A chemical technique for separation of ferromanganese minerals, carbonate minerals and absorbed trace elements from pelagic sediments. Chem. Geol. 2(3), 249-262.

Claff, S. R., Sullivan, L.A., Burton, E.D., Bush, R.T., 2010. A sequential extraction procedure for acid sulfate soils: partitioning of iron. Geoderma 155(3-4), 224-230.

Claypool, G.E., Threlkeld, C.N., 1983. Anoxic diagenesis and methane generation in sediments of the Blake Outer Ridge, Deep Sea Drilling Project Site 533, Leg 76. Initial Report Deep Sea Drilling Project, 76, 391-402.

Crémière, A., Strauss, H., Sebilo, M., Hong, W. L., Gros, O., Tocny, J., Henry, F., Gontharet, S., Laverman, A.M., 2017. Sulfur diagenesis under rapid accumulation of organic-rich sediments in a marine mangrove from guadeloupe (french west indies). Chem. Geol. 454, $67-79$.

Davison, W., 1993. Iron and manganese in lakes. Earth-Sci. Rev. 34(2), 119-163.

De Prunelé, A., Ruffine, L., Riboulot, V., Peters, C.A., Croguennec, C., Guyader, V., Pape, T., 


\section{ACCEPTED MANUSCRIPT}

Bollinger, C., Bayon, G., Caprais, J.-C., Germain, Y., Donval J.-P., Marsset, T.,

Bohrmann, G., Geli, L., Rabiu, A., Lescanne, M., Cauquil, E., Sultan, N., 2017. Focused hydrocarbon - migration in shallow sediments of a pockmark cluster in the Niger Delta (Off Nigeria). Geochem. Geophy. Geosy. 18(1), 93-112.

Donisa, C., Steinnes, E., Mocanu, R., 2008. Combination of Different Extractants to Assess Binding Forms of Some Elements in Soil Profiles. Commun. Soil Sci. Plan. Anal. 39(1-2), 177-186.

Dupré, S., Scalabrin, C., Grall, C., Augustin, J., Henry, P., Şengör, A. M. Şengör, C., Görür, N., Çağatay, M.N., Géli L, 2015. Tectonic and sedimentary controls on widespread gas emissions in the Sea of Marmara: results from systematic, shipborne multibeam echo sounder water column imaging. J. Geophys. Res.: Sol. Ea., 120(5), 2891-2912.

Egger, M., Jilbert, T., Behrends, T., Rivard, C., Slomp, C.P., 2015a. Vivianite is a major sink for phosphorus in methanogenic coastal surface sediments. Geochim. Cosmochim. Ac. $169,217-235$.

Egger, M., Rasigraf, O., Sapart, C.J., Jilbert, T., Jetten, M.S., Röckmann, T., van der Veen, C., Bândă, N., Kartal, B., Ettwig, K.F., Slomp, C.P., 2015b. Iron-mediated anaerobic oxidation of methane in brackish coastal sediments. Environ. Sci. Technol. 49(1), $277-283$

Gasperini, L., Polonia, A., Çağatay, M.N., Bortoluzzi, G., Ferrante, V., 2011. Geological slip rates along the North Anatolian Fault in the Marmara region. Tectonics 30(6), TC6001.

Gasperini et al. Earthquake geology in the Sea of Marmara. To be submitted.

Géli, L., Henry, P., Zitter, T., Dupré, S., Tryon, M., Çağatay, M.N., de Lépinay, B.M., Le 


\section{ACCEPTED MANUSCRIPT}

Pichon, X., Şengör, A.M.C., Görür, N., Natalin, B., Uçarkuş G., Özeren, S., Volker, D.,

Gasperini, L., 2008. Gas emissions and active tectonics within the submerged section of the North Anatolian Fault zone in the Sea of Marmara. Earth Planet. Sc. Lett. 274(1-2), $34-39$.

German, C.R., Elderfield, H., 1990. Application of the Ce anomaly as a paleoredox indicator: the ground rules. Paleoceanography 5(5), 823-833.

Glasby, G.P., Schulz, H.D., 1999. Eh, pH diagrams for Mn, Fe, Co, Ni, Cu and As under seawater conditions: application of two new types of Eh, $\mathrm{pH}$ diagrams to the study of specific problems in marine geochemistry. Aquat. Geochem. 5(3), 227-248.

Gröger, J., Franke, J., Hamer, K., Schulz, Horst. D., 2010. Quantitative Recovery of Elemental Sulfur and Improved Selectivity in a Chromium-Reducible Sulfur Distillation. Geostand. Geoanal. Res. 33(1): 17-27.Gürgey, K., Philip, R.P., Clayton, C., Emiroglu, H., Siyako, M., 2005. Geochemical and isotopic approach to maturity/source/mixing estimation for natural gas and associated condensates in the Thrace Basin, NW Turkey. Appl. Geochem. 20, 2017-2037.

Huerta-Diaz, M.A., Morse, J.W., 1992. Pyritization of trace metals in anoxic marine sediments. Geochim. Cosmochim. Ac. 56, 2681-2702.

Hunger, S., Benning, L.G., 2007. Greigite: a true intermediate on the polysulfide pathway to pyrite. Geochem. T. 8(1), 485-493.

Karabulut, H., Schmittbuhl, J., Özalaybey, S., Lengliné, O., Kömeç-Mutlu, A., Durand, V., Bouchon, M., Daniel, G., Bouinet, M.P., 2011. Evolution of the seismicity in the eastern Marmara Sea a decade before and after the 17 August 1999 Izmit earthquake. 


\section{ACCEPTED MANUSCRIPT}

Tectonophysics 510(1-2), 17-27.

Kasten, S., Freudenthal, T., Gingele, F.X., Schulz, H. D., 1998. Simultaneous formation of iron-rich layers at different redox boundaries in sediments of the Amazon deep-sea fan. Geochim. Cosmochim. Ac. 62(13), 2253-2264.

Kvenvolden, K.A., 1988. Methane hydrate - A major reservoir of carbon in the shallow geosphere? Chem. Geol. 71(1-3), 41-51.

Larner, B.L., Seen, A.J., Townsend, A.T., 2006. Comparative study of optimised BCR sequential extraction scheme and acid leaching of elements in the certified reference material NIST 2711. Anal. Chim. Acta 556(2), 444-449.

Larrasoana, J.C., Roberts, A.P., Musgrave, R.J., Gracia, E., Pinero, E., Vega, M., Martinez-Ruiz, F., 2007. Diagenetic formation of greigite and pyrrhotite in gas hydrate marine sedimentary systems. Earth and Planet. Sci. Lett. 261, 350-366.

Leifer, I., Patro, R.K., 2002. The bubble mechanism for methane transport from the shallow sea bed to the surface: a review and sensitivity study. Cont. Shelf Res. 22(16), $2409-2428$.

Liu, Y., Miah, M.R.U, Schmitt, R.A., 1988. Cerium: a chemical tracer for paleo-oceanic redox conditions. Geochim. Cosmochim. Ac. 52(52), 1361-1371.

Liu, Y., Yang, H., Lu, H., Ruffine, L., The Difference in Foraminifera Occurrence between Western High and East Basin in the Sea of Marmara. 9th International Conference on Gas hydrates, Denver, USA, June 25-30, 2017.

Lovley, D.R., 1991. Dissimilatory iron(III) and manganese(IV) reduction. Microbiol. Rev. 55, 259-287. 


\section{ACCEPTED MANUSCRIPT}

Lyons, T.W., Severmann, S., 2006. A critical look at iron paleoredox proxies: new insights from modern euxinic marine basins. Geochim. Cosmochim. Ac. 70(23), 5698-5722.

Malinverno, A., Pohlman, J.W., 2011. Modeling sulfate reduction in methane hydrate-bearing continental margin sediments: Does a sulfate-methane transition require anaerobic oxidation of methane? Geochem. Geophy. Geosy. 12(7), 4080-4093.

MarsiteCruise Report. Géli L, Ruffine L, Henry P, 2014. DOI: 10.17600/14000500. http://campagnes.flotteoceanographique.fr/campagnes/14000500/

März, C., Hoffmann, J., Bleil, U., de Lange, G., Kasten, S., 2008. Diagenetic changes of magnetic and geochemical signals by anaerobic methane oxidation in sediments of the Zambezi deep-sea fan (SW Indian Ocean), Mar. Geol. 255, 118-130.

Morgan, B., Burton, E.D., Rate, A.W., 2012. Iron monosulfide enrichment and the presence of organosulfur in eutrophic estuarine sediments. Chem. Geol. 296-297(2), 119-130.

Nealson, K.H., Saffarini, D., 1994. Iron and manganese in anaerobic respiration: environmental significance, physiology, and regulation. Annu. Rev. Microbiol. 48(1), $311-343$.

Newton, R. J., Bottrell, S. H., Dean, S. P., Hatfield, D., Raiswell, R., 1995. An evaluation of the use of the chromous chloride reduction method for isotopic analyses of pyrite in rocks and sediment. Chem. Geol. 125(3), 317-320.

Pattan, J.N., Pearce, N.J.G., Mislankar, P.G., 2005. Constraints in using Cerium-anomaly of bulk sediments as an indicator of paleo bottom water redox environment: a case study from the Central Indian Ocean Basin. Chem. Geol. 221(3-4), 260-278.

Poulton, S.W., Canfield, D.E., 2005. Development of a sequential extraction procedure for 


\section{ACCEPTED MANUSCRIPT}

iron: implications for iron partitioning in continentally derived particulates. Chem. Geol. 214(3), 209-221.

Poulton, S.W., Krom, M.D., Raiswell, R., 2004. A revised scheme for the reactivity of iron (oxyhydr)oxide minerals towards dissolved sulfide. Geochim. Cosmochim. Ac. 68(18), $3703-3715$.

Poulton, S.W., Raiswell, R., 2005. Chemical and physical characteristics of iron oxides in riverine and glacial meltwater sediments. Chem. Geol. 218(3), 203-221.

Raiswell, R., Canfield, D.E., Berner, R.A., 1994. A comparison of iron extraction methods for the determination of degree of pyritisation and the recognition of iron-limited pyrite formation. Chem. Geol. 111(1-4), 101-110.

Raiswell, R., Canfield, D.E., 2012. The Iron Biogeochemical Cycle Past and Present. Geochem. Perspect. 1(1), 1-220.

Raiswell, R., Newton, R., Wignall, P.B., 2001. An Indicator of Water-Column Anoxia: Resolution of Biofacies Variations in the Kimmeridge Clay (Upper Jurassic, U.K.). J. Sediment. Res. 71(2), 286-294.

Reeburgh, W.S., 1976. Methane consumption in Cariaco Trench waters and sediments. Earth Planet. Sc. Lett. 28(3), 337-344.

Rickard, D., Luther, G.W.I., 2013. Chemistry of Iron Sulfides. Cheminform 107(2), 514-562.

Ritt, B., Sarrazin, J., Caprais, J. C., Noël, P., Gauthier, O., Pierre, C., Henry, P., Desbruyères, D., (2010). First insights into the structure and environmental setting of cold-seep communities in the Marmara Sea. Deep-Sea Res. I 57(9), 1120-1136.

Roberts, A.P., 2015. Magnetic mineral diagenesis. Earth-Science Reviews 151, 1-47. 


\section{ACCEPTED MANUSCRIPT}

Roberts, A.P., Weaver, R., 2005. Multiple mechanisms of remagnetization involving sedimentary greigite (FeS). Earth Planet. Sci. Lett 231, 263-277.

Rowan, C.J., Roberts, A.P., Broadbent, T., 2005. Reductive diagenesis, magnetite dissolution, greigite growth and paleomagnetic smoothing in marine sediments: A new review. Earth Planet. Sci. Let. 277, 223-235.

Ruffine, L., Fandino, T.O., Etoubleau, J., Cheron, S., Donval, J.-P., Germain, Y., Ponzevera, E., Guyader, V., Dennielou, B., Etiope, G., Gasperini, L., Bortoluzzi, G., Henry, P., Grall, C., Cagatay, M., Namik, Charlou, J.-L., Geli, L., 2012. Geochemical Dynamics of the Natural-Gas Hydrate System in the Sea of Marmara, Offshore Turkey. In Geochemical Dynamics of the Natural-Gas Hydrate System in the Sea of Marmara, Offshore Turkey,

Advances in Natural Gas Technology, Dr. Hamid Al-Megren (Ed.), ISBN: 978-953-51-0507-7. pp.29-56.

Ruffine, L., Donval, J.P., Croguennec, C., Burnard, P., Lu, H., Germain, Y., Legoix, L., Bignon, L., Cagatay, M.N., Marty, B., Madre, D., Pitel-Roudaut, M., Henry, P., Géli, L., Accepted. Multiple gas reservoirs are responsible for the gas emissions along the Marmara fault network. Deep-Sea Res. II. In press.

Ruffine, L., Germain, Y., Polonia, A., De Prunelé, A., Croguennec, C., Donval, J., Pitel-Roudaut M., Ponzevera E., Caprais J.-C., Brandily C., Grall C., Bollinger C., Geli L., Gasperini. L. 2015. Pore water geochemistry at two seismogenic areas in the Sea of Marmara. Geochem. Geophy. Geosy. 16(7), 2038-2057.

Ruffine, L., Ondreas, H., Blanc-Valleron, M.M., Teichert, B.M.A., Scalabrin, C., Rinnert, E., Birot, D., Croguennec, C., Ponzevera, E., Pierre, C., Donval, J.P., Alix, A.S., Germain, 


\section{ACCEPTED MANUSCRIPT}

Y., Bignon, L., Etoubleau, J., Caprais, J.C., Knoery, J., Lesongeur, F., Thomas, B., Roubi,

A., Legoix, L., Burnard, P., Chevalier, N., Lu, H., Dupré, S., Fontanier, C., Dissard, D., Olgun, N., Yang, H., Strauss, H., Özaksoyj, V., Perchoc, J., Podeur, C., Tarditi, C., Özbekij, E., Guyader, V., Marty, B., Madre, D., Grall, C., Embriaco, D., Polonia, A., Gasperini, L., Cagatay, M.N., Pitel-Roudaut, M., Henry, P., Géli, L. Multidisciplinary investigation on cold seeps with vigorous gas emissions in the Sea of Marmara (Marsite Cruise): Strategy for site detection and sampling, scientific outcome and research roadmap. Deep-Sea Res. II. To be submitted.

Stumm, W., Sulzberger, B., 1992. The cycling of iron in natural environments: Considerations based on laboratory studies of heterogeneous redox processes. Geochim. Cosmochim. Ac. 56(8), 3233-3257.

Suess, E., 2014. Marine cold seeps and their manifestations: geological control, biogeochemical criteria and environmental conditions. Int. J. Earth Sci. 103(7), $1889-1916$.

Tary, J.B., Géli, L., Henry, P., Natalin, B., Gasperini, L., Ćomoğlu, M., Bardainne, T., 2010. Sea-Bottom Observations from the Western Escarpment of the Sea of Marmara. B. Seismol. Soc. Am. 12(2), 775-791.

Tessier, A., Campbell, P.G.C., Bisson, M., 1979. Sequential extraction procedure for the speciation of particulate trace metals. Anal. Chem. 51(7), 844-851.

Thomson J., Higgs N. C., and Colley S. Diagenetic redistributions of redox-sensitive elements in Northeast Atlantic glacial/interglacial transition sediments. Earth Planet. Sci. Lett. 1996, 139(3-4), 365-377. 
Thomson J, Jarvis I, Green D R H, Green D.A., Clayton T.. Mobility and immobility of redox-sensitive elements in deep-sea turbidites during shallow burial. Geochim. Cosmochim. Acta, 1998, 62(4):643-656.

Toyoda, K., Masuda, A., 1990. Sedimentary environments and chemical composition of Pacific pelagic sediments. Chem. Geol. 88(1-2), 127-141.

Tryon, M.D., Henry, P., Çağatay, M.N., Zitter, T.A.C., Géli, L., Gasperini, L., Burnard, P., Bourlange, S., Grall, C., 2010. Pore fluid chemistry of the North Anatolian Fault Zone in the Sea of Marmara: a diversity of sources and processes. Geochem. Geophy. Geosy. 11(10), 118-137.

Tryon, M.D., Henry, P., Hilton, D.R., 2012. Quantifying submarine fluid seep activity along the North Anatolian Fault Zone in the Sea of Marmara. Mar. Geol. 315(4), 15-28.

USEPA (United States Environmental Protection Agency), Method 3050B: Acid digestion of sediments, sludges, and soils," revision 2. US EPA, Washington, DC 1996. https://www.epa.gov/homeland-security-research/epa-method-3050b-acid-digestion-sedi ments-sludges-and-soils

Wallmann, K., Aloisi, G., Haeckel, M., Obzhirov, A., Pavlova, G., Tishchenko, P., 2006. Kinetics of organic matter degradation, microbial methane generation, and gas hydrate formation in anoxic marine sediments. Geochim. Cosmochim. Acta 70, 3905-3927. doi:10.1016/j.gca.2006.06.003

Wang, S., Yan, W., Chen, Z., Zhang, N., Chen, H., 2014. Rare earth elements in cold seep carbonates from the southwestern Dongsha area, northern South China Sea. Mar. Petrol. Geol. 57(2), 482-493. 


\section{ACCEPTED MANUSCRIPT}

Worsfold, P.J., Lohan, M.C., Ussher, S.J., Bowie, A.R., 2014. Determination of dissolved iron in seawater: a historical review. Mar. Chem. 166, 25-35.

Zitter, T.A.C., Henry, P., Aloisi, G., Delaygue, G., Çağatay, M.N., de Lepinay, B.M., AlSamir, M., Fornacciari, F., Tesmer, M., Pekdeger, A., Wallmann, K., Lericolais, G., 2008. Cold seeps along the main Marmara Fault in the Sea of Marmara (Turkey). Deep-Sea Res. I. 55(4), 552-570.

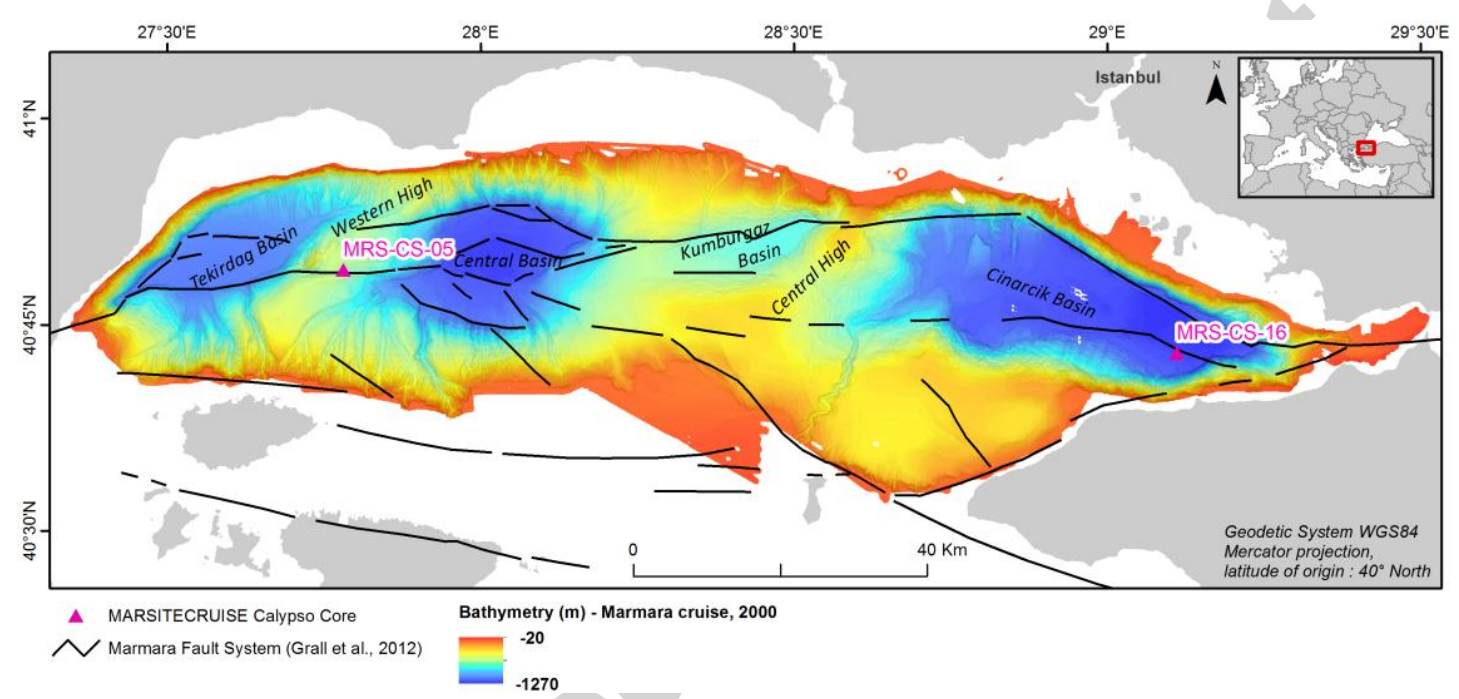

Fig. 1. Map of the research area and the sample locations in the Sea of Marmara. 


\section{ACCEPTED MANUSCRIPT}

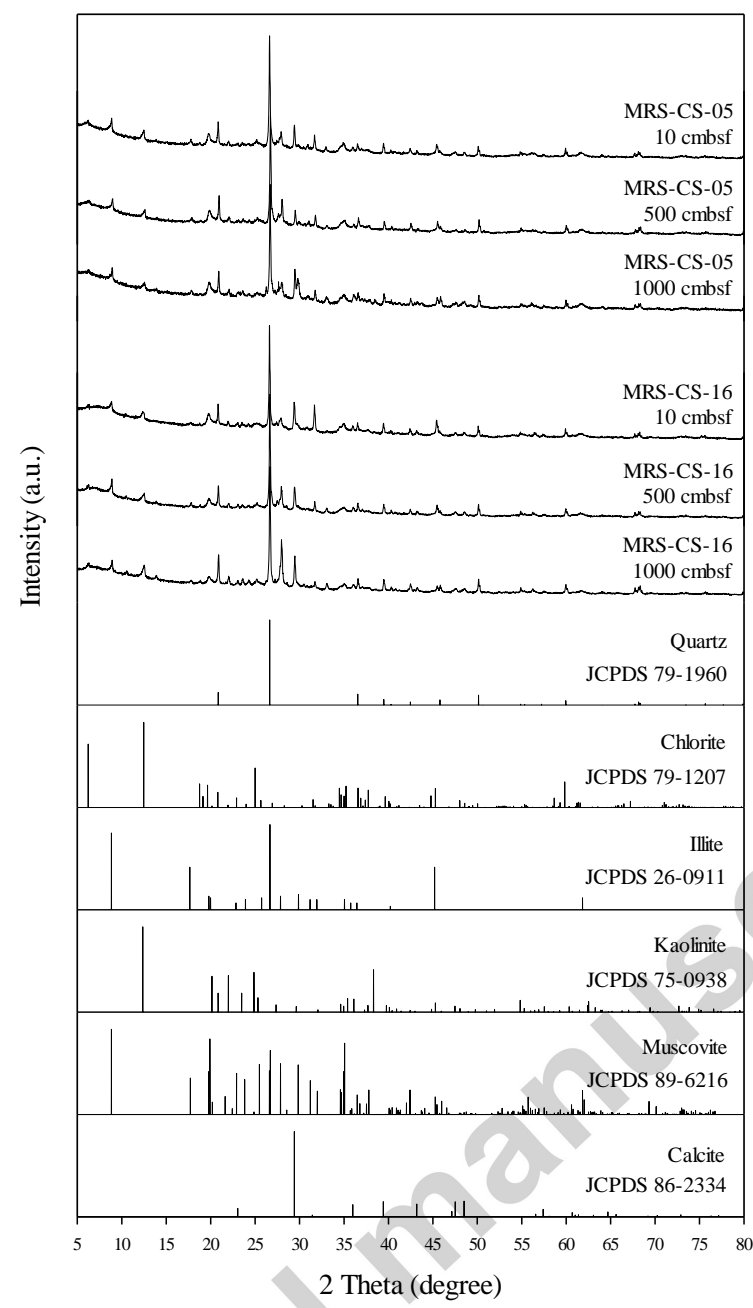

Fig. 2. X-ray powder diffraction patterns of the sediment samples from the Western High and Cinarcik Basin, the Sea of Marmara. 


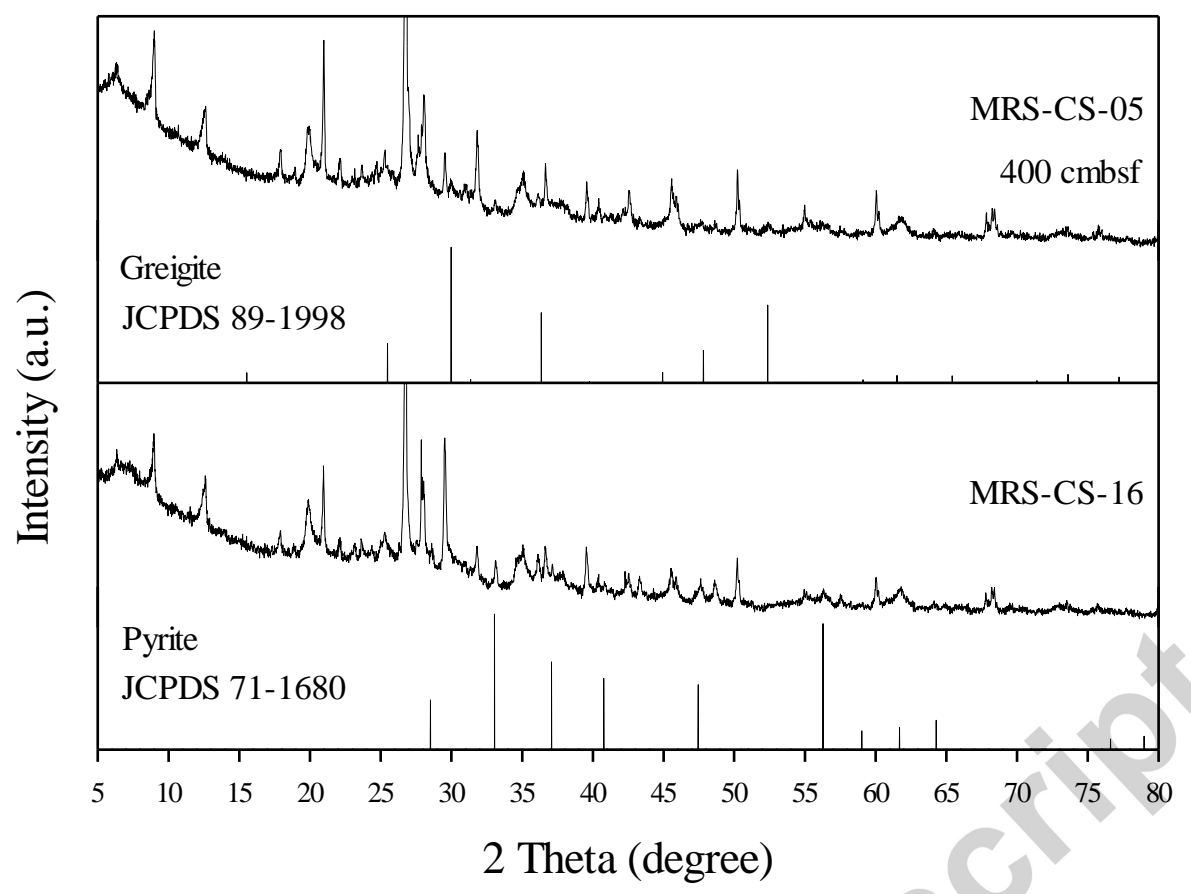

Fig. 3. XRD patterns documenting the presence of greigite at the depth with the maximum $\mathrm{Fe}$ concentration in Core MRS-CS-05 on the Western High, the Sea of Marmara.
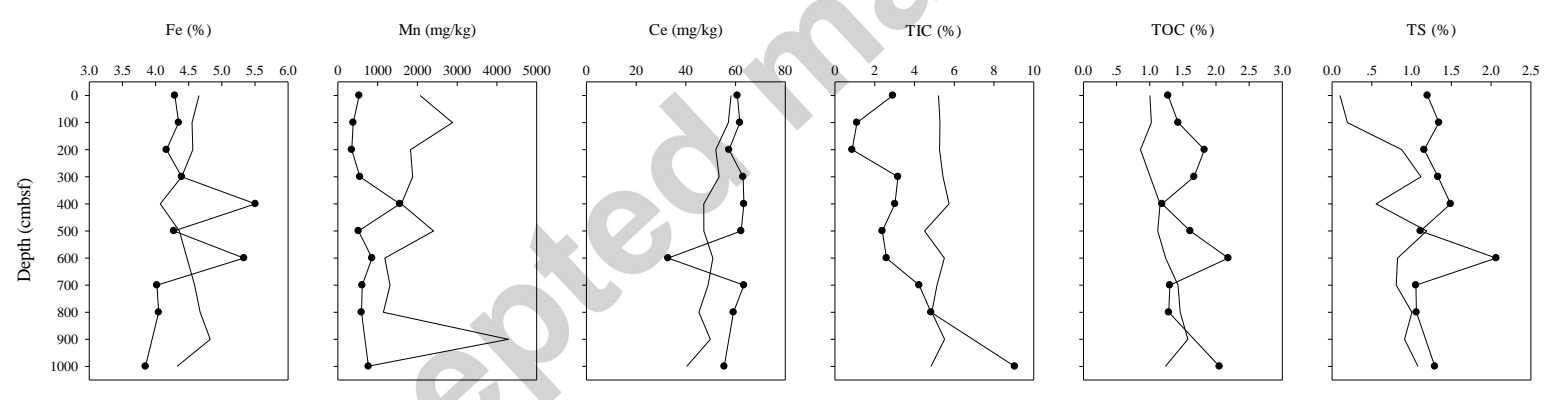

Fig. 4. Vertical distributions of $\mathrm{Fe}, \mathrm{Mn}, \mathrm{Ce}$, and other associated elements in the sediment cores from the Sea of Marmara. Solid circles: MRS-CS-05; empty circles: MRS-CS-16. 


\section{ACCEPTED MANUSCRIPT}

$\mathrm{Al} / \mathrm{Ti}(\mathrm{g} \mathrm{Al} / \mathrm{g} \mathrm{Ti})$

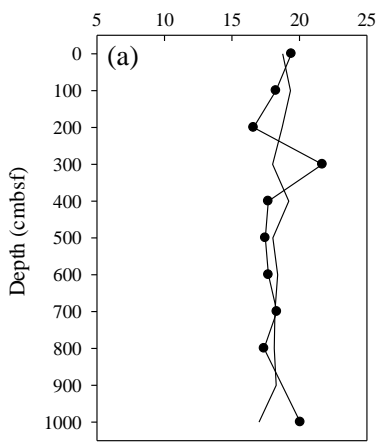

$\mathrm{Fe} / \mathrm{Al}(\mathrm{g} \mathrm{Fe} / \mathrm{g} \mathrm{Al})$

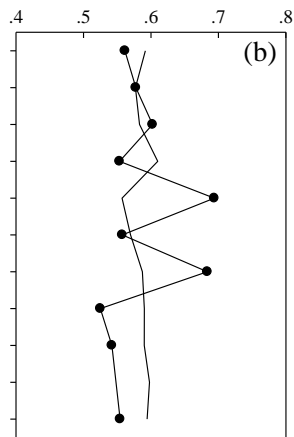

$\mathrm{Mn} / \mathrm{Al}(\mathrm{mg} \mathrm{Mn} / \mathrm{g} \mathrm{Al})$

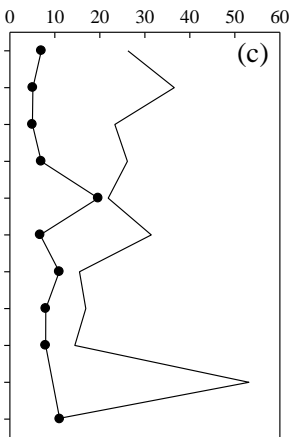

Fig. 5. Al/Ti ratios in the sediments and aluminum-normalized $\mathrm{Fe}$ and $\mathrm{Mn}$ distributions of the bulk sediments from the Sea of Marmara. Solid circles: MRS-CS-05; empty circles:

MRS-CS-16.
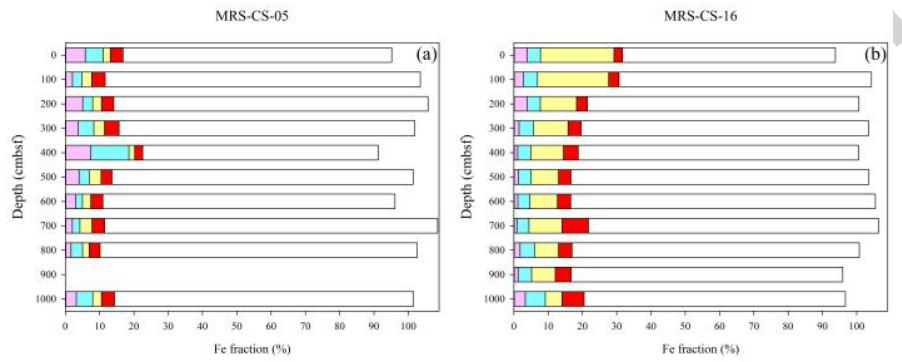

$\square$ siderite, ankerite $\square$ ferrihydrite, lppidocrocite $\square$ gocthitc, hematite, akagencitc $\square$ magnetile $\square$ bound in silicates

MRS-CS-05

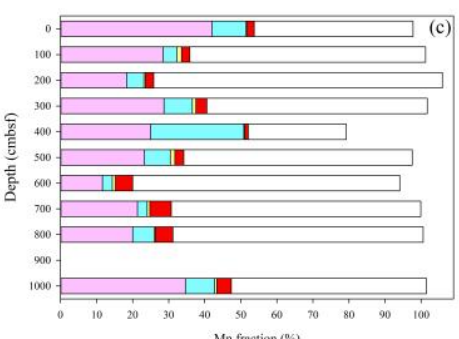

$\square$ Carbonate-associated $\square$ Easily reducible (amorphous) $\square$ Reducible (crystalline) $\square$ Recalcitrant $\square$ Residual
MRS-CS-16

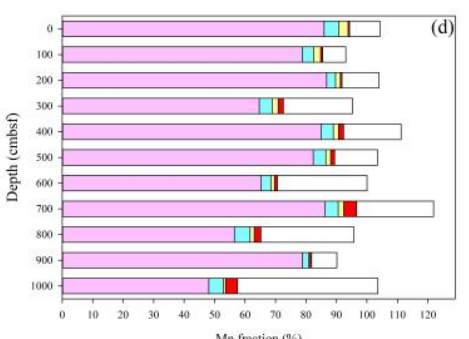

Fig. 6. The speciation of Fe and Mn in the sediments from the Sea of Marmara. (a): the speciation of Fe on the Western High; (b): the speciation of Fe in Cinarcik Basin; (c): the speciation of Mn on the Western High; (d): the speciation of Mn in Cinarcik Basin. 


\section{ACCEPTED MANUSCRIPT}

AVS $(\%)$

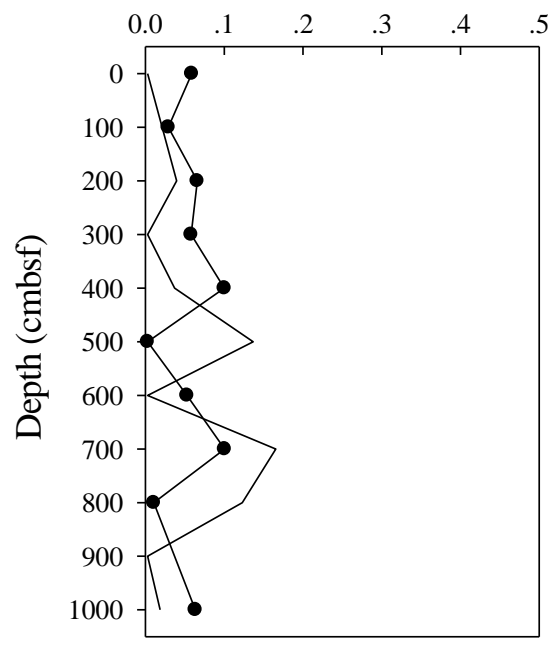

CRS $(\%)$

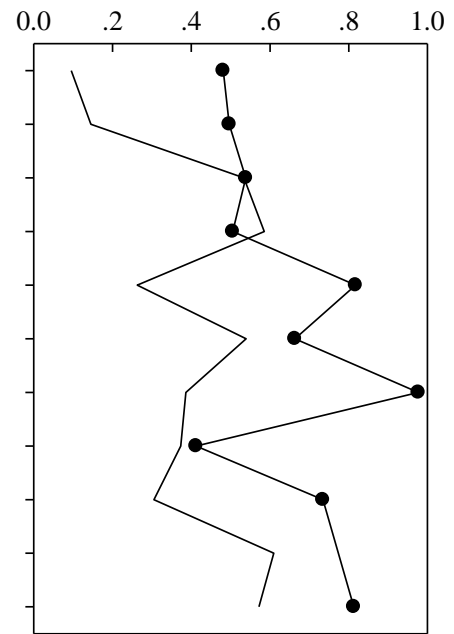

Fig. 7. Contents of acid-volatile sulfide (AVS) and chromium-reducible sulfur (CRS) in sediments from the Sea of Marmara. Solid circles: MRS-CS-05; empty circles: MRS-CS-16.

Table 1. Summary of the Fe sequential extraction procedure for soil and sediment

\begin{tabular}{|c|c|c|c|}
\hline $\begin{array}{l}\text { Iron } \\
\text { fractionation }\end{array}$ & Extractant & Remark & Reference \\
\hline $\begin{array}{l}\text { Exchangeable } \\
\mathrm{Fe}\end{array}$ & $1 \mathrm{~mol} \mathrm{~L}^{-1} \mathrm{MgCl}_{2}$ extracted for $1 \mathrm{~h}$ & $\begin{array}{l}\text { Both } \mathrm{MgCl}_{2} \text { and } \mathrm{CaCl}_{2} \text { are } \\
\text { commonly used to extract } \\
\text { exchangeable metal ions, including } \\
\mathrm{Fe} \text {. }\end{array}$ & $\begin{array}{l}\text { Tessier et al., } \\
1979\end{array}$ \\
\hline Carbonate Fe & $\begin{array}{l}1 \mathrm{~mol} \mathrm{~L}^{-1} \mathrm{Na} \text {-acetate brought to } \\
\mathrm{pH} 4.5 \text { with acetic acid, extracted } \\
\text { for } 24 \mathrm{~h}\end{array}$ & $\begin{array}{l}\text { The most suitable and effective } \\
\text { extraction conditions for siderite } \\
\text { and ankerite }\end{array}$ & $\begin{array}{l}\text { Chester and } \\
\text { Hughes, } 1967\end{array}$ \\
\hline $\begin{array}{l}\text { Amorphous } \\
\text { Fe oxides }\end{array}$ & $\begin{array}{l}1 \mathrm{~mol} \mathrm{~L}^{-1} \text { hydroxylamine- } \mathrm{HCl} \\
\text { extracted for } 48 \mathrm{~h}\end{array}$ & $\begin{array}{l}\text { Easily reducible oxides, including } \\
\text { ferrihydrite and lepidocrocite }\end{array}$ & $\begin{array}{l}\text { Poulton and } \\
\text { Canfield, } \\
2005\end{array}$ \\
\hline Organic Fe & $\begin{array}{l}\text { Concentrated } \mathrm{H}_{2} \mathrm{O}_{2} \text { or } 0.1 \mathrm{~mol} \mathrm{~L}^{-1} \\
\text { Na-pyrophosphate }\left(\mathrm{Na}_{4} \mathrm{P}_{2} \mathrm{O}_{7}\right), \mathrm{pH} \\
10 \text {, extracted for } 16 \mathrm{~h}\end{array}$ & $\begin{array}{l}\text { The strong oxidant } \mathrm{H}_{2} \mathrm{O}_{2} \text { does not } \\
\text { allow organic- and pyrite-bound } \\
\text { iron to be distinguished and } \\
\mathrm{Na}_{4} \mathrm{P}_{2} \mathrm{O}_{7} \text { can dissolve some of the } \\
\text { poorly crystalline iron oxides. }\end{array}$ & $\begin{array}{l}\text { Donisa et al., } \\
2008\end{array}$ \\
\hline $\begin{array}{l}\text { Crystalline Fe } \\
\text { oxides }\end{array}$ & $\begin{array}{l}0.35 \text { mol L } \\
-1 \\
\mathrm{~L}^{-1} \text { acetic acid } / 0.2 \mathrm{~mol} \\
\mathrm{~g} \mathrm{~L}^{-1} \text { sodium citrate buffer with } 50\end{array}$ & $\begin{array}{l}\text { CBD is a strong reducing agent that } \\
\text { extracts the broadest range of } \\
\text { crystalline Fe oxides. }\end{array}$ & $\begin{array}{l}\text { Claff et al., } \\
2010\end{array}$ \\
\hline
\end{tabular}




\section{ACCEPTED MANUSCRIPT}

extracted for $4 \mathrm{~h}$

\begin{tabular}{|c|c|c|c|}
\hline $\begin{array}{l}\text { Recalcitrant } \\
\text { oxide }\end{array}$ & $\begin{array}{l}0.2 \mathrm{~mol} \mathrm{~L} \\
\text { oxalate } / 0.17 \text { mol } \mathrm{L}^{-1} \text { oxalic acid } \\
\text { solution, extracted for } 2 \mathrm{~h}\end{array}$ & $\begin{array}{l}\text { The suitability of ammonium } \\
\text { oxalate as an extractant of } \\
\text { magnetite, a ferrous-ferric oxide } \\
\text { mineral, was evaluated. }\end{array}$ & $\begin{array}{l}\text { Poulton and } \\
\text { Canfield, } \\
2005\end{array}$ \\
\hline Fe sulfide & $\begin{array}{l}\text { Concentrated } \mathrm{HCl} \text { or } \mathrm{HNO}_{3} \text {, } \\
\text { extracted for } 2 \mathrm{~h} \\
1 \mathrm{~mol} \mathrm{~L}^{-1} \mathrm{CrCl}_{2} \text {, extracted for } 2 \mathrm{~h} \\
\text { in } \mathrm{N}_{2} \text { atmosphere at sub-boiling } \\
\text { temperatures }\end{array}$ & $\begin{array}{l}\mathrm{Fe} \text { monosulfide and pyrite }\left(\mathrm{FeS}_{2}\right) \\
\text { are most commonly extracted; } \mathrm{Fe} \\
\text { sulfides also include marcasite } \\
\left(\mathrm{FeS}_{2}\right) \text {, greigite }\left(\mathrm{Fe}_{3} \mathrm{~S}_{4}\right) \text { and } \\
\text { mackinawite }(\mathrm{FeS}) \text {, which are } \\
\text { sensitive to low pH and oxygen. }\end{array}$ & $\begin{array}{l}\text { Huerta-Diaz } \\
\text { and Morse, } \\
\text { 1992; } \\
\text { Raiswell et } \\
\text { al., 1994; } \\
\text { Newton et al., } \\
1995\end{array}$ \\
\hline Silicate Fe & $\begin{array}{l}\text { Concentrated } \mathrm{HCl} \\
\mathrm{HNO}_{3}, \mathrm{HCl} \text {, and } \mathrm{H}_{2} \mathrm{O}_{2} \text {, hot digest }\end{array}$ & $\begin{array}{l}\text { Divided into poorly reactive sheet } \\
\text { silicate } \mathrm{Fe} \text { and unreactive silicate } \mathrm{Fe}\end{array}$ & $\begin{array}{l}\text { Poulton and } \\
\text { Raiswell, } \\
2005\end{array}$ \\
\hline Total $\mathrm{Fe}\left(\mathrm{Fe}_{\mathrm{T}}\right)$ & $\mathrm{HNO}_{3}, \mathrm{HCl}, \mathrm{HF}$, and $\mathrm{HClO}_{4}$ & Microwave digestion & USEPA, 1996 \\
\hline
\end{tabular}

Table 2. The site details for this research in the Sea of Marmara

\begin{tabular}{cccccc}
\hline Site & Core & Latitude & Longitude & Water depth & Core Length \\
\hline Western High & MRS-CS-05 & N 40 49.027791 & E 27 46.853486 & $657 \mathrm{~m}$ & $907 \mathrm{~cm}$ \\
Cinarcik Basin & MRS-CS-16 & N 40 49.977194 & E 296.703129 & $1237 \mathrm{~m}$ & $1013 \mathrm{~cm}$ \\
\hline
\end{tabular}

Table 3. The sequential extraction protocol for studying the speciation of Fe and Mn in sediments

\begin{tabular}{|c|c|c|c|c|}
\hline Step & Fraction & Extraction & Fe species ${ }^{a}$ & Mn species ${ }^{b}$ \\
\hline 1 & Carbonate-associated & $\begin{array}{l}1 \mathrm{~mol} \mathrm{~L}^{-1} \mathrm{Na} \text {-acetate } \\
\text { brought to } \mathrm{pH} 4.5 \text { with } \\
\text { acetic acid for } 24 \mathrm{~h}\end{array}$ & $\begin{array}{l}\text { siderite }\left(\mathrm{FeCO}_{3}\right) \\
\text { and ankerite }\end{array}$ & $\begin{array}{l}\mathrm{MnCO}_{3} \text { and } \mathrm{Mn}-\mathrm{Ca} \\
\text { carbonates }\end{array}$ \\
\hline 2 & $\begin{array}{l}\text { Easily reducible } \\
\text { (amorphous) oxides }\end{array}$ & $\begin{array}{l}1 \mathrm{~mol} \mathrm{~L}^{-1} \\
\text { hydroxylamine- } \mathrm{HCl} \text { for } \\
48 \mathrm{~h}\end{array}$ & $\begin{array}{l}\text { ferrihydrite } \\
\left(\mathrm{Fe}_{5} \mathrm{HO}_{8} \cdot 4 \mathrm{H}_{2} \mathrm{O}\right) \\
\text { and lepidocrocite } \\
(\gamma \text {-FeOOH })\end{array}$ & $\begin{array}{l}\text { birnessite } \\
\left(\mathrm{Na}_{0.7} \mathrm{Ca}_{0.3} \mathrm{Mn}_{7} \mathrm{O}_{14} \cdot 2.8 \mathrm{H}_{2} \mathrm{O}\right) \text {, } \\
\text { vernadite }\left(\delta \text { - } \mathrm{MnO}_{2}\right) \text {, nsutite } \\
\left(\gamma-\mathrm{MnO}_{2}\right) \text {, and pyrolusite } \\
\left(\beta-\mathrm{MnO}_{2}\right)\end{array}$ \\
\hline 3 & $\begin{array}{l}\text { Reducible } \\
\text { (crystalline) oxides }\end{array}$ & $\begin{array}{l}\text { Na-dithionite buffer } \\
\text { brought to } \mathrm{pH} 4.8 \text { with } \\
0.35 \mathrm{~mol} \mathrm{~L}{ }^{-1} \text { acetic } \\
\text { acid/ } 0.2 \mathrm{M} \text { sodium } \\
\text { citrate for } 2 \mathrm{~h}\end{array}$ & $\begin{array}{l}\text { goethite } \\
(\alpha-\mathrm{FeOOH}) \text {, } \\
\text { hematite } \\
\left(\alpha-\mathrm{Fe}_{2} \mathrm{O}_{3}\right) \text {, and } \\
\text { akageneite } \\
(\beta-\mathrm{FeOOH})\end{array}$ & $\begin{array}{l}\text { manganite }(\gamma-\mathrm{MnOOH}) \text { and } \\
\text { bixbyite }\left(\alpha-\mathrm{Mn}_{2} \mathrm{O}_{3}\right)\end{array}$ \\
\hline 4 & Recalcitrant oxides & $\begin{array}{l}0.2 \mathrm{~mol} \mathrm{~L}^{-1} \text { ammonium } \\
\text { oxalate } / 0.17 \mathrm{~mol} \mathrm{~L}^{-1} \\
\text { oxalic acid solution for } \\
2 \mathrm{~h}\end{array}$ & magnetite $\left(\mathrm{Fe}_{3} \mathrm{O}_{4}\right)$ & hausmannite $\left(\mathrm{Mn}_{3} \mathrm{O}_{4}\right)$ \\
\hline
\end{tabular}




\begin{tabular}{llll}
\hline 5 Residual & $\begin{array}{l}\mathrm{HNO}_{3}, \mathrm{HCl}, \mathrm{HF}, \text { and } \\
\mathrm{HClO}_{4}\end{array}$ & $\begin{array}{l}\text { occur in the } \\
\text { residual silicate } \\
\text { phase }\end{array}$ \\
\hline
\end{tabular}

Note: ${ }^{\mathrm{a}}$ as reported by Poulton and Canfield (2005); ${ }^{\mathrm{b}}$ developed from the Eh-pH diagrams for Mn and its chemical similarity to Fe (Brookins 1988; Glasby and Schulz, 1999)

Table 4. Correlations between the specific elements in the sediments

\begin{tabular}{|c|c|c|c|c|c|c|c|}
\hline \multirow{7}{*}{ 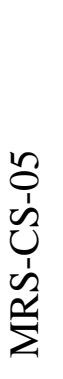 } & & $\mathrm{Fe}$ & $\mathrm{Mn}$ & $S$ & $\mathrm{Ce}$ & $\mathrm{P}$ & TOC \\
\hline & $\mathrm{Fe}$ & 1 & $0.739 *$ & $0.785 * *$ & -0.425 & $0.725^{*}$ & 0.032 \\
\hline & $\mathrm{Mn}$ & & 1 & 0.444 & -0.107 & $0.719 *$ & -0.149 \\
\hline & $S$ & & & 1 & $-0.824 * *$ & 0.432 & 0.542 \\
\hline & $\mathrm{Ce}$ & & & & 1 & 0.051 & $-0.740^{*}$ \\
\hline & $\mathrm{P}$ & & & & & 1 & -0.068 \\
\hline & TOC & & & & & & 1 \\
\hline \multirow{7}{*}{ 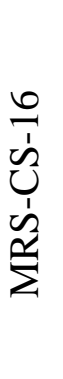 } & & $\mathrm{Fe}$ & $\mathrm{Mn}$ & $S$ & $\mathrm{Ce}$ & $\mathrm{P}$ & TOC \\
\hline & $\mathrm{Fe}$ & 1 & 0.466 & -0.129 & 0.348 & 0.487 & 0.371 \\
\hline & $\mathrm{Mn}$ & & 1 & -0.190 & 0.432 & 0.033 & 0.134 \\
\hline & S & & & 1 & $-0.689^{*}$ & -0.496 & 0.303 \\
\hline & $\mathrm{Ce}$ & & & & 1 & 0.130 & -0.500 \\
\hline & $\mathrm{P}$ & & & & & 1 & 0.101 \\
\hline & TOC & & & & & & 1 \\
\hline
\end{tabular}

* The correlation is significant at the 0.05 level. ** The correlation is significant at the 0.01 level. 